in the sixth segment; faint, transverse bands, leaving the sutures indefinitely lighter. There are no median hairs, but several long ones on each side near the submarginal bands; last segment entire, truncate or very slightly concave, with sides rounded; a row of short hairs across the posterior margin of the last segment, and a group of strong, close-set hairs on each side on the ventral surface.

Measurements.

\begin{tabular}{lcc}
\multicolumn{1}{c}{ Length: } &, 2.10 & Width: \\
Head & .52 & .56 \\
Prothorax & .32 & .42 \\
Metathorax & .32 & .64 \\
Abdomen & 1.06 & .84
\end{tabular}

Named in honor of the collector, Dr. Emelia Snethlage of the Museu Goeldi at Pará.

\title{
A NEW GENUS AND THREE NEW SPECIES OF PHORID A FROM NORTH AMERICA, WITH NOTES ON TWO RECENTLY ERECTED GENERA (CREPIDOPACHYS AND PRONOMIOPHORA ENDERLEIN).
}

\section{By J. R. Malloch,}

\section{Bureau of Entomology, U. S. Department of Agriculture.}

Dr. G. Enderlein in describing (Stettiner entom. Zeit., 1912, p. 16) some Phoridæ from southern Brazil erected the genus Crepidopachys with the new species longirostrata as type. The legend to the figure on same page, which is presumably that of the wing of this species, indicates that it is C. costalis, Enderlein. Thus costalis is evidently a synonym of longirostrata Enderlein. In his remarks on the affinities of the genus he indicates that it differs from Pronomiophora, Enderlein, 1912, in having the costa thickened. This latter genus is not described prior to the former but at page 46 of the same publication, and therefore ought to be considered as erected on page 16, and on page 46 appear as Pronomiophora Enderlein and not "nov. gen." Independent of these trifling errors however I fear that there are some others which are of much more consequence. From the description I am forced to the conclusion that in erecting Crepidopachys and Pronomiophora Enderlein added two quite unnecessary genera inasmuch as both 
are quite evidently synonyms of Dohrniphora Dahl. The swollen costa of Crepidopachys is I am quite confident a female character just as it is in Phora thoracica Meigen and in several species in Aphiochata (costalis v. Roser, epeira Brues, etc.), and though the sex of the type is not given by Enderlein I am, I believe, correct in accepting it as a female. In the male the costa will probably prove to be normal or at least only slightly swollen. The bristling of the legs is indicated only as "Mittelschiene wie bei Phora mit einer Machrochæta nahe der Basis der Aussenseite." No further indication is given as to their bristling and this is given only in his remarks on affinities, not in the description. I consider the genus as synonymous with Dohrniphora Dahl.

Pronomiophora I consider also as a synonym of Dohrniphora. It agrees in every respect with the description of that genus and like nearly all the females in the genus the one here described, rostrata Enderlein, has the long proboscis, one of the principal characteristics of the genus. I cannot conceive how this position has been created except through an inadequate knowledge of the group and the literature on it. If we carry out this system of erecting genera for species

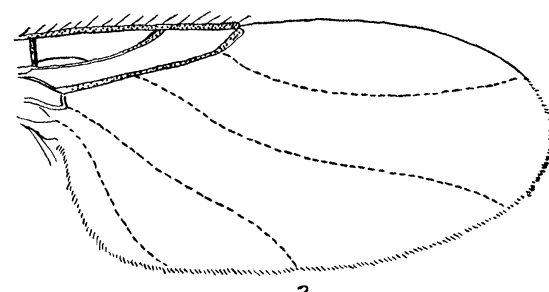

2 .

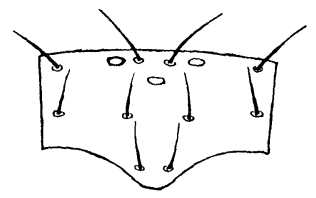

7 .

Fig. 1. Hypocerina barberi, gen. et sp. nov. 1 , front; 2 , wing. which possess only such trifing deviations from the types of existing genera as these two, the ultimate outcome will be that we will have every species in a different genus.

Hypocerina gen. nov.

Head of moderate size, frons (fig. 1) broad and short with 2 rows of four bristles, one vertical and one preocellar, only one pair of postantennal reclinate bristles present; anterior margin of frons produced in center, laterally excised; ocelli distinct, third antennal joint oval, slightly pointed, arista apical, basal joints elongate; epistome produced, palpi of moderate size, proboscis fleshy. Thorax and abdomen as in Aphiochota. Wings with neuration as in Puliciphora, the second thick vein unforked and the me diastinal vein present; four distinct thin veins (fig. 2). Legs with isolated spines.

Type of genus: Hypocerina barberi, sp. nov. 


\section{Hypocerina barberi sp. nov.}

Female: Black, subshining. Lower row of frontal bristles straight, post-antennal pair divergent. Antennæ brownish, third joint with very short whitish pilosity, arista pale, only very indistinctly pubescent on third section; palpi brown, moderately bristled. Mesonotum with short hairs and two wide placed dorso-central posterior bristles on disk, scutellum with two bristles. Abdomen opaque black, first segment very short, second dilated posteriorly, two and one-half times as long as first and with a few lateral posterior bristles, third and succeeding segments each about two-thirds as long as second. Legs brown, tibiæ and tarsi paler, fore tibiæ with one antero-dorsal bristle at basal third, mid tibiæ with one antero-dorsal and one postero-dorsal bristle at basal third and one dorsal at apical fourth, hind tibiæ with one antero-dorsal and one postero-dorsal bristle at basal third one almost dorsal bristle at below middle and a very short bristle at near apex on antero-dorsal surface, mid and hind tibial spurs long, hind pair with a shorter spur on anterior side, hind tarsus twice as long as tibia. Wings clear, costa short of middle, first division almost twice as long as second, costal fringe very short. Halteres black. Length $1.5 \mathrm{~mm}$.

Type: Cat. No. 15323 U. S. National Museum.

Locality: Dead Run, Fairfax County, Virginia Oct. 26, 1912. (Barber and Schwarz). Four females, taken from a bottle which had been sunk in the ground and baited with cheese as a beetle trap.

This species bears a resemblance to the males of Puliciphora Dahl, but the spinose tibiæ separate it at once from that genus as does also the presence of wings and halteres in the female. It also resembles the smaller species in the genus Hypocera from which it is separated by the presence of only two instead of three rows of frontal bristles.

Named in honor of Mr. H. S. Barber.

\section{Aphiochæta flavipalpis sp. nov.}

Male: Brown, shining; frons slightly broader than long, lower post-antennal bristles less than half the size of the upper pair, outer pair in first row of bristles nearly in line transversely with upper post-antennals, the inner pair a little lower than post-antennals, antennæ small, brown, arista longer than breadth of frons, slightly pubescent; palpi yellow, large and projecting, a very few weak bristles present; pleuræ brown, yellow on lower portions, mesopleura with a number of equal sized bristles, scutellum with four equal sized bristles; abdomen subopaque brown, segments narrowly pale bordered posteriorly, a few short, scattered hairs on all segments, those on apical segment most distinct, hypopygium large, projecting, gray dusted, ventral processes large, anal protuberance of good size, clear yellow; legs yellow, hind femora darkened at apices, hind tibial setulæ weak, most dis- 
tinct on middle; wings grayish, costa to middle, first division as long as next two together, third one-fourth as long as second, fringe as long as fork of third vein, fourth vein leaving at beyond fork, slightly bent at base and ending slightly recurved at in front of wing tip; halteres yellow. Length $2 \mathrm{~mm}$.

Type; Cat. No. 15324 U. S. National Museum.

One male in National Museum, District of Columbia, Oct. 19th, 1912, (R. C. Shannon). Very similar to projecta Becker from which the unswollen fore tarsus separates it.

\section{Aphiochæta subciliata sp. nov.}

Male and female: Black; frons glossy, about one-third longer than broad in male, slightly less in female; lower post-antennal bristles about one-half as large as upper pair in both sexes, center pair of bristles in first row much below outer pair and slightly below upper post-antennals, nearer center of frons than outer pair which are close to eye-margins; antennæ black, third joint normal in size, arista about one-third longer than length of frons, almost bare; palpi pale yellow, of normal size, moderately black-bristled, mesonotum shining, pleuræ glossy black, mesopleuræ with numerous short bristles and one long, backwardly directed one which reaches to base of halter; scutellum with two bristles; abdomen shining black, first segment shorter than second, second to fourth slightly decreasing in length, fifth and sixth elongated; surfaces of all segments with short hairs; male anal protuberance yellow, hypopygium small, but slightly exposed; legs black, fore coxæ and femora yellow, fore tibiæ and tarsi, mid coxæ, trochanters and tarsi, and extreme bases of hind tibiæ brownish; hind femora flattened, hind tibial setulæ distinct and rather widely placed (9-10); wings narrow, slightly infuscated, especially along veins, costa slightly short of middle in male, to middle in female, first division equal to next two, third division one-third as long as second, fourth vein bent at base, running slightly upward to distinctly in front of wing tip and slightly recurved at apex; fringe short and closely placed; halteres yellow, stalk darker. Length 1-2 mm.

Type: Cat. No. 15325 U. S. National Museum.

Locality: Two males, and 11 females, Washington, District of Columbia, October, 6-29, 1912, one female, Livingston Heights, Virginia, October 29, 1912 (R. C. Shannon).

This species may be mistaken in at least the male sex for ciliata, Zetterstedt but the costal divisions are different, and in the female of ciliata the fourth abdominal segment is very much shortened, being only one-third as long as the third. 

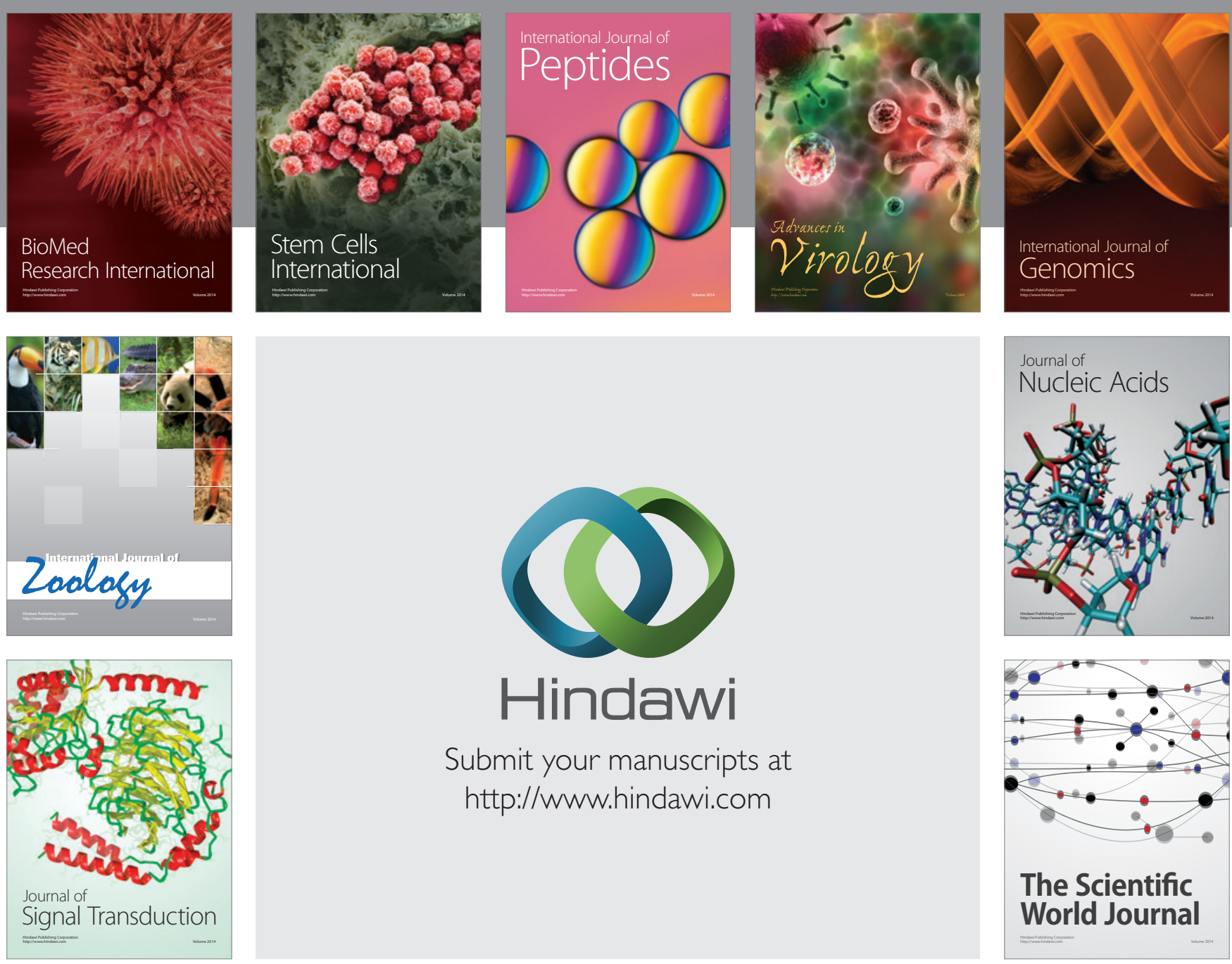

Submit your manuscripts at

http://www.hindawi.com
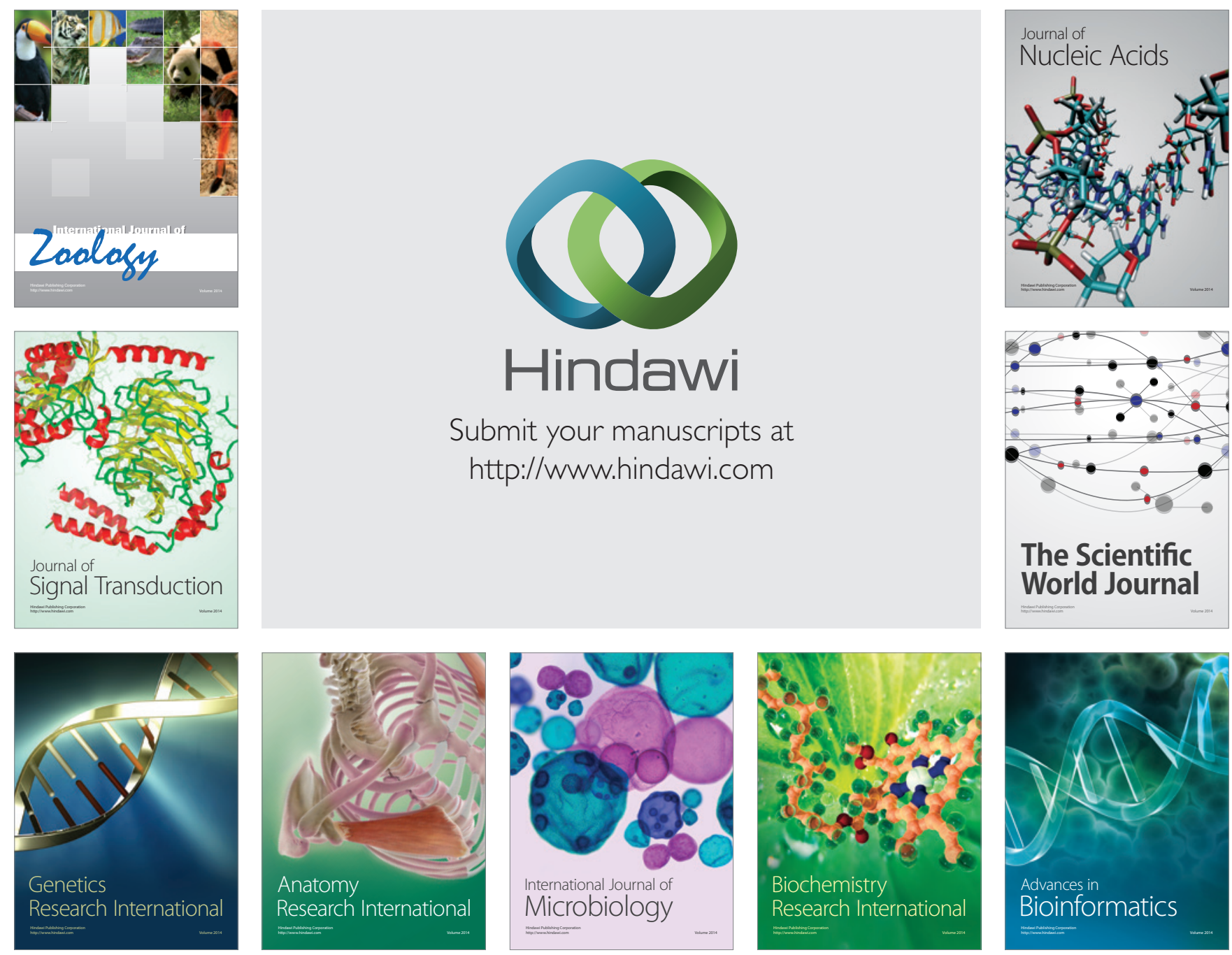

The Scientific World Journal
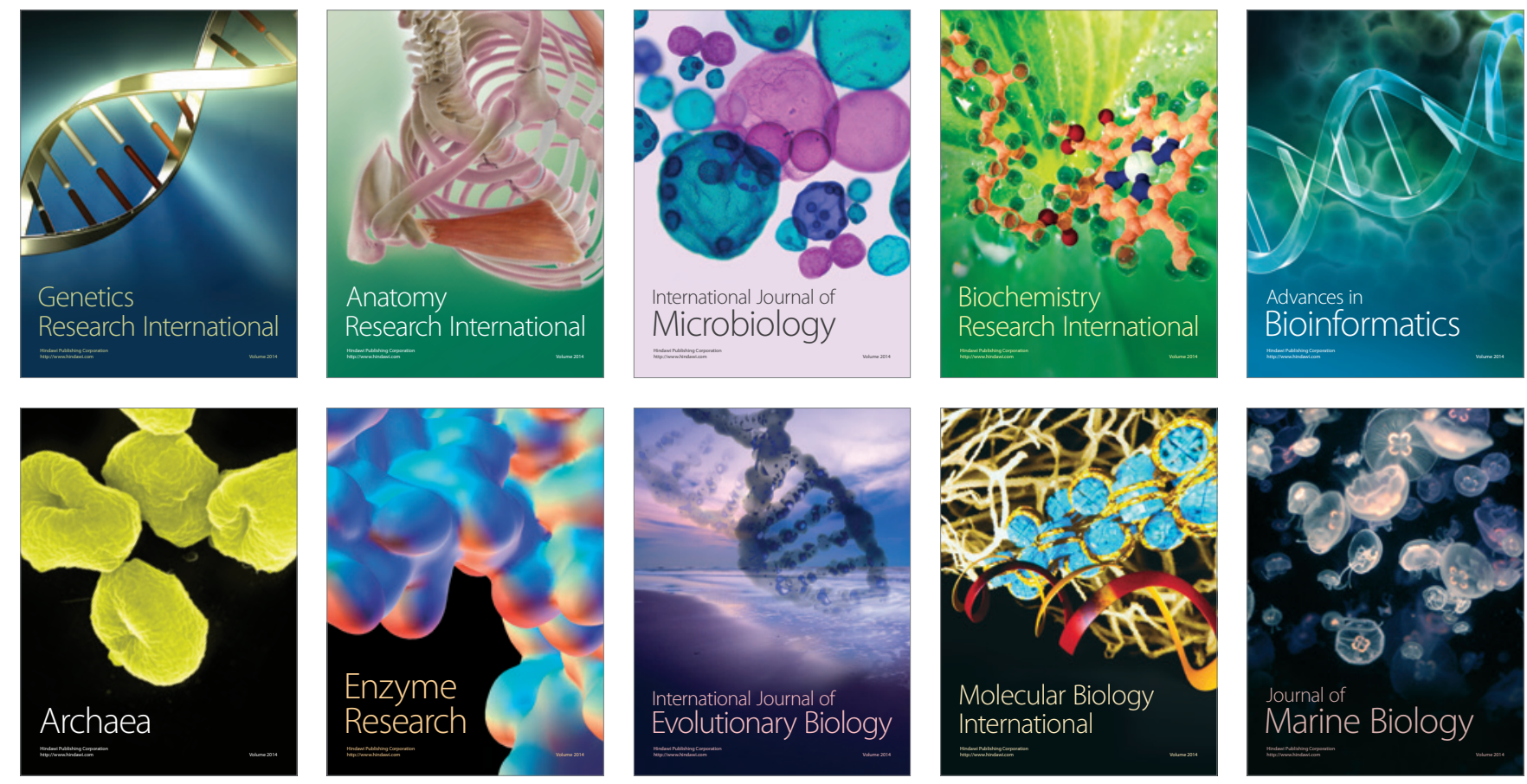